critical features of both infantile and adult human glycogen storage disease type II. J Biol Chem 1998;273:19086-19092.

27. Phillips MF, Smith PE, Carroll N, Edwards RH, Calverley PM. Nocturnal oxygenation and prognosis in Duchenne muscular dystrophy. Am J Respir Crit Care Med 1999;160:198202.

28. Vianello A, Bevilacqua M, Salvador V, Cardaioli C, Vincenti E. Long-term nasal intermittent positive pressure ventilation in advanced Duchenne's muscular dystrophy [see comments]. Chest 1994;105:445-448.

29. Bach JR. Perspectives of nasal ventilation: indications, methods and complementary techniques for patients with neuromuscular disease. Eur Respir Rev 1993;3:243-244.

30. Simonds AK. Nasal intermittent positive pressure ventilation in neuromuscular and chest wall disease. Monaldi Arch Chest Dis 1993;48:165-168.

\title{
Neuro/mages
}
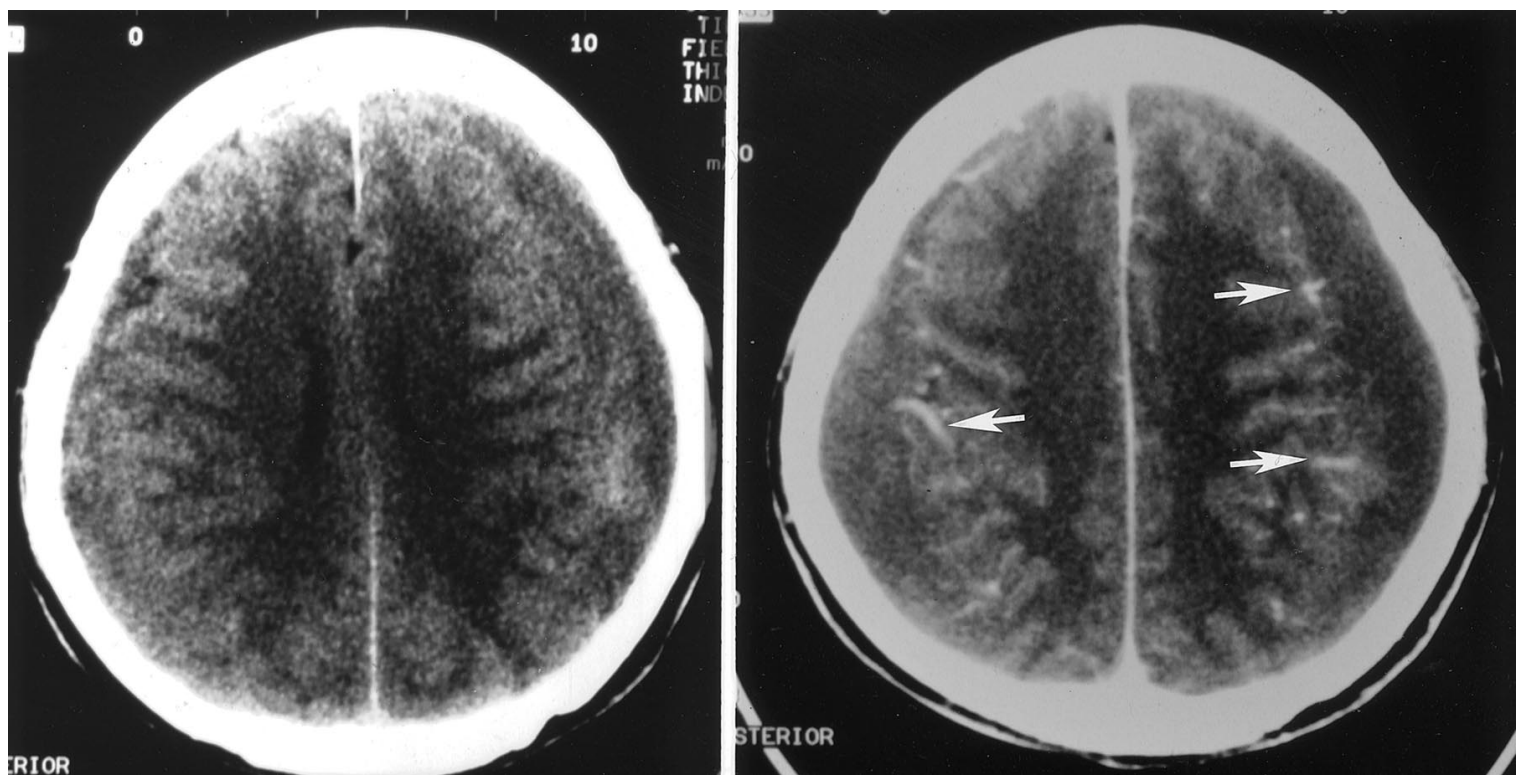

Figure. Noncontrast brain CT scan (left) shows isodensity in extra-axial region. Contrasted CT scan (right) shows the isodense lesions with enhancement and medial displacement of cortical veins (arrows), indicating bilateral chronic subdural hematomas.

\section{Deteriorating parkinsonism and subdural hematomas}

Samuel M. Chou, MD, Ludwig Gutmann, MD, Morgantown, WV

A 69-year-old physician with stable PD (well controlled with carbidopa/levodopa, pramipexole, and selegiline for 4 years) had rapid deterioration of various findings of parkinsonism to a semi-invalid state over 1 month. An increase in carbidopa/levodopa dosage was without benefit. Recalling minor head trauma several weeks before deterioration onset prompted per- formance of a CT scan (figure), with subsequent evacuation of bilateral subdural hematomas. He returned to his active baseline state 2 days later.

Rapid deterioration in PD is unusual. Subdural hematomas causing this have occasionally been reported.1,2 Recognition and treatment of subdural hematomas resulted in a favorable outcome.

1. Accardi R, Arnetoli G, Ammannati F. Parkinsonism caused by chronic subdural hematoma. A case report. Ital J Neurol Sci 1985;6:109-111.

2. Wiest RG, Burgunder JM, Krauss JK. Chronic subdural hematomas and parkinsonian syndromes. Acta Neurochir (Wien) 1999;141:753-757. 


\section{Neurology}

\section{Deteriorating parkinsonism and subdural hematomas}

Samuel M. Chou and Ludwig Gutmann

Neurology 2001;57;1295

DOI 10.1212/WNL.57.7.1295

This information is current as of October 9, 2001

\section{Updated Information \& Services}

\section{References}

Subspecialty Collections

Permissions \& Licensing

\section{Reprints}

including high resolution figures, can be found at: http://n.neurology.org/content/57/7/1295.full

This article cites 2 articles, 0 of which you can access for free at: http://n.neurology.org/content/57/7/1295.full\#ref-list-1

This article, along with others on similar topics, appears in the following collection(s):

\section{Brain trauma}

http://n.neurology.org/cgi/collection/brain_trauma

CT

http://n.neurology.org/cgi/collection/ct

Parkinson's disease with dementia

http://n.neurology.org/cgi/collection/parkinsons_disease_with_demen tia

Parkinson's disease/Parkinsonism

http://n.neurology.org/cgi/collection/parkinsons_disease_parkinsonis $\mathrm{m}$

Information about reproducing this article in parts (figures,tables) or in its entirety can be found online at:

http://www.neurology.org/about/about_the_journal\#permissions

Information about ordering reprints can be found online:

http://n.neurology.org/subscribers/advertise

Neurology ${ }^{\circledR}$ is the official journal of the American Academy of Neurology. Published continuously since 1951, it is now a weekly with 48 issues per year. Copyright . All rights reserved. Print ISSN: 0028-3878.

Online ISSN: 1526-632X.

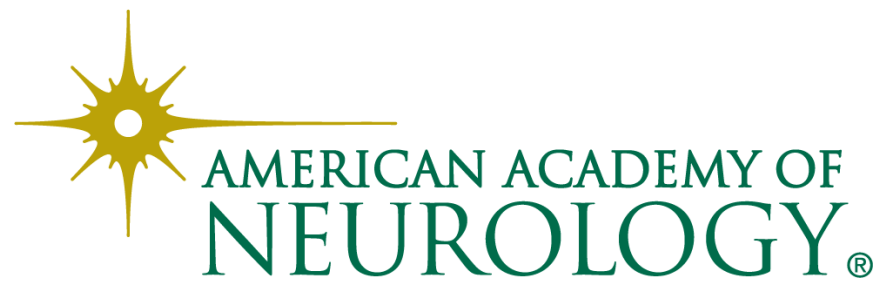

